\title{
Super Women: Solusi Terhadap Kekerasan Pada Perempuan?
}

Oleh: Syamsudin

Dosen Fakultas Humaniora dan Budaya, Jurusan Bahasa dan Sastra Inggris.

\begin{abstract}
Violence on women will never stop! This statement could be right looking at the recent condition experienced by women. There are at least two factors causing women always become the victim of many violence and are always marginalized. The first factor because of the patriarchy culture system and the second one, because of the inappropriate interpretation of Koran verses. Those two factors really have placed women to be weak in many aspects of life. Moreover, they only have low education. They become passive and dependent. They are even as weak as their physic compared with men. That's why, they are easy to become the victim of many violence. Danger is always staying in front of them. But, knowing about this, can't women free themselves from this bad condition? The answer is clear; Yes, they can! But what to do? There is only one thing that can help women free from being colonialized. What's that? "Super Women"! Right, "Super Women" is the only answer for them to be free from being the victim of many violence and being marginalized in many aspects of life. But, to become "Super Women" is not easy. To be "Super Women", they must get high education. However, there is nothing impossible in this world. That's why, they must educate themselves soon. Using the knowledge they get they can change their world. Next, their life won't be filled with story of becoming the victim of many violence or being marginalized, on the reverse, they could manage their own life to be "Super Women". And only by becoming "Super Women", based on the religion corridor women would be successful in career, social organization and household fully. Finally, they could maximize their life to be useful for themselves, family, society and the country.
\end{abstract}

Key Terms: violence on women, education, "Super Women”.

\section{Pendahuluan}

"Wanita dijajah pria sejak dulu. Dijadikan perhiasan sangkar madu.., Namun ada kala pria tak berdaya tekuk lutut...”

Begitulah bunyi sepenggal syair lagu pop lawas di era 70-an. Saat itu, lagu ini begitu popular. Kaum remaja sampai orang tua gemar menyanyikannya. Sampai sekarang, lagu inipun sesekali masih menghiasi beberapa stasiun TV dan Radio lokal. Lagu ini biasa diputar dalam acara tembang kenangan. Terus terang lagu ini memang enak didengar.

Bahkan saat mendengarkan lagu ini, tiada terasa, terkadang mulut kita turut bersenandung menirukan syairnya.

Namun dari irama dan juga syair yang nyaman kita dengarkan tersebut, jika diteliti secara mendalam, terutama dari syairnya, akan terlihat jelas adanya kepincangan hubungan antara dua makhluk berlainan jenis ini (pria dan perempuan). Syairnya, secara eksplisit, mengupas kedudukan kaum hawa dalam hubungannya dengan kaum adam. Dalam syair "Wanita dijajah pria sejak dulu" seolah menjelaskan atau bahkan menegaskan bahwa wanita berada dalam keadaan yang tidak menguntungkan berkaitan dengan hubungannya dengan kaum pria. Sejak dulu mereka terjajah! 
Dengan demikian, dari syair lagu di atas bisa disimpulkan bahwa wanita, dari jaman dulu, merujuk sekitar tahun 70-an saat lagu itu ditulis sampai sekarang, dan bahkan hingga saat ini memasuki abad 21, melihat realitas sosial yang ada di masyarakat berkaitan dengan hubungan antara laki-laki dan perempuan mau tidak mau harus kita akui bahwa perempuan memang terjajah.

Keterjajahan yang dialami perempuan itu termanifestasi dalam berbagai bentuk kekarasan. Lantas, kekerasan apa saja yang dialami oleh kaum perempuan? Faktor apa saja yang memuluskan kekerasan yang menimpa kaum hawa ini? Mengacu pada judul artikel ini, siapa pula itu "Super Women?" Apa kontribusi “Super Women” dalam mengatasi kekerasan pada perempuan?

\section{Tiada Hari Tanpa Kekerasan}

Mengerikan! Kekerasan sepertinya tidak akan pernah dapat dipisahkan dari sejarah perjalanan hidup manusia. Kekerasan sudah membudaya. Kekerasan sudah mendarah daging. Sehingga dalam mengarungi kehidupan yang teramat singkat ini, manusia sebagai mahkluk ciptaan Tuhan yang paling sempurna di muka bumi ini, akan selalu mengalami (bisa sebagai pelaku ataupun korban) kekerasan.

Kekerasan sepertinya telah membumi. Sehingga, sejengkal kaki kita melangkah, sedetik waktu berlalu, sehari, sebulan, setahun...hari berganti, telinga dan mata kita akan dengan mudah mendengar dan melihat, langsung maupun tidak langsung, melalui media elektronik dan non elektronik berita seputar kekerasan.

Kekerasan bisa terjadi di mana saja, kapan saja, menimpa siapa saja dan bisa juga dilakukan oleh siapa saja. Dalam hal ini, kekerasan dapat terjadi di rumah, lingkungan tetangga, sekolah, kantor, lapangan sepak bola, kampus, dan lain sebagainya. Kejadiannya dapat berlangsung pada pagi, siang ataupun malam hari. Ia bisa menimpa laki-laki maupun perempuan. Sasaran atau korbannya juga tidak mengenal batas usia. Anak-anak, remaja serta orang tua bisa menjadi obyek kekerasan. Pelakunya juga beragam. Ia dapat dilakukan oleh pelajar, mahasiswa, dosen, pegawai (pemerintah/ swasta), istri, suami, dengan beragam usia baik anak-anak, remaja dan juga para orang tua.

Dari berbagai kekerasan yang ada, yang sering menjadi korban kekerasan adalah perempuan dan anak-anak. Contohnya adalah kasus yang menimpa ibu dan anak di Makasar yang harus tewas akibat adanya kekerasan ekonomi. Ibu dan anak tersebut tewas dalam kondisi kelaparan akibat kemiskinan yang begitu melilit. "Tragis! Ny. Daeng Basse, 35 dan bayi 7 bulan yang dikandungnya meninggal dalam kondisi kelaparan. Tak lama kemudian, anaknya Bahir, yang berusia lima tahun menyusul meninggal akibat kondisi yang sama" 1 .

\footnotetext{
${ }^{1}$ Surya, $2 / 3 / 08$
} 
Kejadian di Makasar di atas, hanyalah salah satu contoh dari berbagai bentuk kekerasan yang ada. Masih ada berbagai bentuk kekerasan lainnya yang 'gampang' menimpa perempuan dan anak-anak. Ia bisa bersifat fisik, psikis, ekonomi dan juga seksual. Hal sesuai dengan pendapat La Pona ${ }^{2}$ yang menggolongkan bentuk kekerasan menjadi 3 yaitu 1) Kekerasan domestik yaitu kekerasan yang terjadi dalam rumah tangga. Kekerasan ini, merupakan bentuk kekerasan non seksual yang meliputi kekerasan fisik, ekonomi, dan psikis; 2) kekerasan publik yaitu kekerasan terhadap perempuan yang dilakukan oleh pihak yang tidak punya hubungan darah atau perkawinan; 3) kekerasan seksual yaitu kekerasan yeng bersifat pelecehan seksual seperti siulan nakal, kedipan mata, memandang penuh nafsu dari ujung rambut sampai mata kaki, olok-olok seks, sampai pada pemerkosaan.

Kekerasan fisik, sering dialami perempuan yang menyandang status sebagai ibu rumah tangga. Kekerasan terhadap perempuan dalam rumah tangga inilah yang sering sebut sebagai KDRT (Kekerasan Dalam Rumah Tangga). Contohnya adalah peristiwa kekerasan yang menimpa seorang ibu muda di wilayah Jakarta. "Diberitakan , karena dibakar api cemburu, seorang suami tega melakukan kekerasan fisik terhadap istrinya yang tengah hamil sembilan bulan. Kekerasan fisik itu sendiri rupanya telah berlangsung cukup lama. Dan karena tidak kuat dengan derita yang dialami akibat siksaan yang berkepanjangan, perempuan muda yang tengah hamil sembilan bulan dan sedang menunggu lahirnya buah hati itu akhirnya menghembuskan nafas terakhir. Kasus meninggalnya ibu muda itupun sekarang dalam penanganan pihak berwajib. Suaminya sudah disel. Ia harus mempertanggung jawabkan semua perbuatan yang mengakibatkan istrinya meninggal dunia."3.

Kasus kekerasan fisik lainnya juga menimpa seorang perempuan muda berparas cantik yang ditemukan tidak bernyawa di bawah sebuah jembatan di salah satu Kecamatan di Banyuwangi. "Seorang perempuan muda berparas cantik ditemukan tidak bernyawa. Ketika Jasad wanita yang diperkirakan berumur 20 -25 tahun itu diangkat, terdapat luka sayatan menganga lebar dari sisi kiri hingga kanan leher. Juga ada luka sayat di dahi korban. Ciri korban berpostur tinggi semampai, berkulit putih, hidung mancung, alis tebal dan rambut lurus sebahu...tak jauh dari tempat korban ditemukan, ada sandal perempuan dengan hak tinggi." 4

Selain disebabkan oleh adanya kekerasan dalam rumah tangga (KDRT), kekerasan fisik pada perempuan, juga dapat diakibatkan oleh penanganan layanan medis yang tidak professional. Ujung-ujungnya adalah terjadinya kegiatan malpraktek dibidang kesehatan. Dalam banyak kasus, kegiatan malpraktek bidang kesehatan ini tidak malah menyembuhkan pasien tapi justru memperparah kondisi pasien. Hal ini pula yang menimpa seorang ibu muda. Ia harus tergolek di rumah sakit karena penanganan persalinan yang

\footnotetext{
${ }^{2}$ Sugihastuti:2007. Gender dan Inferioritas Perempuan. Yogyakarta: Pustaka Pelajar.

${ }^{3}$ Trans 7, Kamis, 13/3/08

${ }^{4}$ Surya, Selasa, 4/3/08
} 
tidak professional. "Dugaan malpraktik kemarin dilaporkan ke Polda Jatim. Ujang didampingi dua orang dari LBH kesehatan Aulia Taswin \& Nopber Siregar melaporkan sejak menjalani persalinan 28 Januari lalu, istrinya, Nur asnah, terus dalam keadaan koma...Saat setelah menjalani persalinan normal dengan biaya Rp. 2.500.000,- Ujang diberitahu kondisi istrinya memburuk sehingga harus dilakukan operasi Caesar...Saat ini ia belum juga sadar meski telah menghabiskan 5 kantong darah. Dari diagnosa RSU Sudhono, diketahui Nur mengalami pembengkakan jantung dan banyak cairan di dalam paru-paru ${ }^{5}$."

Selain kekerasan fisik, perempuan juga mudah menjadi korban kekerasan seksual. Kasus ini dialami oleh seorang guru TK. Ia dipaksa melayani sepupunya selama 2 tahun. "Tak peduli sepupu sendiri, Cahyo Setyo, 28, warga Manukanrejo, tega memperkosa Mawar, 23, yang tinggal serumah dengannya. Bahkan, perbuatan tersebut dilakukan hingga berulangkali sejak 2005 lalu...Kejadian terus berulang setiap ada kesempatan...Tindakan tersangka baru terkuak saat korban pulang ke kampung halamannya dan bercerita pada neneknya. Mengetahui hal tersebut keluarga korban melaporkannya ke Polwil ${ }^{6} . "$

Selain itu, kekerasan seksual juga dialami oleh seorang siswi SMU. Ia diculik selama beberapa hari dan dipaksa menuruti nafsu bejat si penculik. Namun akhirnya perbuatan tak senonohnya itu berakhir setelah ia tertangkap petugas. "Kerja keras Satreskrim Polres Gresik membuahkan hasil. Penculik Oktavia, warga jalan RA Kartini Gang XX Kecamatan Gresik yaitu Imam Chrisyangto, 25, berhasil ditangkap di Kuta Denpasar Bali pada Minggu (2/3) sekitar pukul $20.00 \mathrm{WIB}^{7}$.

Hal yang sama juga menimpa seorang siswi pelajar SMP. Ia telah dijual seharga Rp. 400.000,- oleh temannya yang juga kakak kelasnya untuk melayani laki-laki hidung belang. "Polisi terus mendalami kasus trafficking yang pelaku dan korbannya masih di bawah umur. Lina (bukan nama sebenarnya), 17, sebagai pelaku dan Sofia (juga nama samaran) 15, sebagai korban sama-sama sudah dimintai keterangan oleh polisi...Korban mengaku masih perawan. Dia mengaku bersyukur belum dijamah oleh pria yang membokingnya. Dalam pemeriksaan, korban bersyukur berhasil diselamatkan petugas. Kasus prostitusi dengan korban siswi SMP tersebut merupakan yang kedua dalam dua bulan terakhir. Pada 17/2/08 lalu, Unit PPA Polwiltabes juga menangkap Alin, purel sebuah karaoke yang menjual siswi SMP di hotel ${ }^{8}$."

Siswi SMP di atas hanyalah salah satu contoh dari banyak kasus perdagangan perempuan yang belum terungkap. Mereka adalah korban 'trafficking'. Mereka biasa dipekerjakan di luar jawa atau bahkan luar negri. Sebagian besar dari mereka rata-rata adalah perempuan dengan tingkat pendidikan rendah dan bingung dalam menatap masa depan sehingga mereka menuruti begitu saja setiap tawaran kerja yang datang. Perempuanperempuan malang tersebut terjebak oleh bujuk rayu calo trafficking yang banyak

\footnotetext{
${ }^{5}$ Sindo, Minggu, 9/3/08

${ }^{6}$ Ibid.,

${ }^{7}$ Surya, Selasa, 4/3/08

${ }^{8}$ Jawa Pos, Senin, 10/3/08
} 
berkeliaran di banyak terminal bus dan juga stasiun kereta api. “...Dede menjelaskan, dalam mencari sasaran, Bintoro dan Mulyani biasa 'cangkruk' di terminal atau stasiun di Surabaya. Mirip makelar atau calo pekerja seks komersial (PSK), begitu melihat wanita muda yang tampak bingung mereka menawarkan jasa. Tersangka menawarkan pekerjaan pembantu rumah tangga (PRT) dengan gaji lumayan. Korban-korbannya ditawari kerja di Surabaya. Kalau tertarik, langsung dibawa kepenampungan CV SAS di jalan Muteran, “ papar Dedi. "Setelah masuk penampungan , para wanita tersebut tidak dipekerjakan di Surabaya. Tapi, dikirim ke luar Jawa, bahkan ke luar negeri, seperti Singapura dan Malaysia secara illegal" lanjutnya. Atas jasanya itu, perekrut mendapat upah 1.500.000,per calo $\mathrm{TKW}^{9}$.

Selain kekerasan fisik dan seksual, kekerasan lainnya yang dialami perempuan adalah kekerasan ekonomi. Kekerasan ini dapat disebabkan oleh faktor kemiskinan yang begitu mencekik. Dampaknya, guna mencukupi kebutuhan hidupnya, korban kekerasan ekonomi ini dapat melakukan apa saja untuk memenuhi kebutuhan hidup mereka. Hal ini pula yang dilakukan oleh seorang ibu muda yang melakukan tindak pencurian di sebuah swalayan di Surabaya hanya untuk memenuhi kebutuhan susu anaknya setelah ditinggal pergi suaminya yang tidak bertanggung jawab. "Tidak ada pilihan selain mencuri.

Begitulah pembelaan pembelaan Wiwik Widayati, warga jalan Gayung Kebonsari. Janda muda 24 tahun ini mengaku terpaksa mencuri susu untuk kebutuhan anak keduanya yang baru berusia tujuh bulan...Wiwik mengaku kehidupannya mulai sulit setelah berpisah dengan suaminya beberapa bulan lalu. Wiwik tidak tahu kemana perginya sang suami. Ia sendiri tidak bekerja, sementara ia harus merawat dua anak ${ }^{10}$."

Dampak kekerasan ekonomi selain menyebabkan terjadinya kemiskinan juga kelaparan. Kasus kelaparan yang berujung pada gizi buruk yang kemudian mengantarkan korban pada kematian rupanya sedang marak melanda tanah air kita yang tercinta ini. Salah satu contohnya adalah kasus gizi buruk yang menimpa salah satu keluarga miskin di Makasar. Disini, Seorang ibu muda yang tengah hamil 7 bulan harus meninggal bersama dengan anaknya yang berusia 5 tahun dan juga janin yang dikandungnya. "Tragis sekali nasib Nyonya Daeng basse, 35 tahun. Bersama bayi 7 bulan yang dikandungnya, Basse meninggal dunia dalam keadaan kelaparan. Tak lama kemudian, anaknya yang masih berusia 5 tahun juga meninggal akibat kondisi yang sama. Meski dinas kesehatan (Dinkes) setempat kemarin menyatakan bahwa ibu dan anaknya itu meninggal akibat muntaber, namun melihat kondisi ekonomi keluarga yang sangat memprihatinkan, gizi buruk diduga kuat mempercepat kematian mereka ${ }^{11}$."

Sementara itu, jika kekerasan ekonomi dapat menyebabkan kematian, kekerasan psikis/mental biasanya mengakibatkan depresi ataupun stress. Bila kekerasan psikis ini

\footnotetext{
${ }^{9}$ Ibid.,

${ }^{10}$ Sindo, Selasa, 11/3/08

${ }^{11}$ Surya, Minggu, 2/3/08
} 
berlangsung secara terus menerus dengan tekanan yang begitu berat pada akhirnya dapat menyebabkan penderita kekerasan mengalami depresi berat. Bahkan, kekerasan psikis yang begitu berat dapat menyebabkan pada ke-gilaan. Lebih jauh, penderitanya dapat menjadi seorang pembunuh berdarah dingin. Dalam beberapa kasus, kekerasan psikis dapat juga disebabkan oleh adanya kekerasan ekonomi. Bahkan, kasus ini rupanya sedang 'ngetrend' terjadi di Negara kita ini. Contohnya adalah kasus pembunuhan yang dialakukan oleh seorang ibu rumah tangga yang menjadi gila akibat tidak kuat menahan kerasnya hidup dan cengkeraman kemiskinan dan kemudian tega menghilangkan nyawa buah hatinya sendiri. Hal ini sesuai dengan pendapat Wakil Presiden Yusuf Kalla, dalam sebuah keterangan pers di kantornya, yang menyatakan bahwa "kasus ibu bunuh anak bisa disebabkan oleh faktor ekonomi, masalah rumah tangga atau bercerai, atau masalah kejiwaan ${ }^{12}$."

Dari gambaran di atas terlihat jelas bahwa kekerasan terhadap perempuan termanifestasi dalam berbagai bentuk dan kejadiannya bisa terjadi dimana saja, kapan saja, menimpa siapa saja dan dilakukan oleh siapapun juga. Kasus kekerasan tehadap perempuan sepertinya tidak akan pernah berhenti. Bahkan kian lama cenderung meningkat. Hal ini sejalan dengan data dari Komisi Nasional (Komnas) Perempuan. "Kasus kekerasan terhadap perempuan dan diskriminasi gender semakin meningkat dari tahun ke tahun. Kasus kekerasan terhadap perempuan meningkat empat kali lipat. Berdasarkan catatan Komisi Nasional (Komnas) Perempuan, sejak disyahkannya undang undang (UU) kekerasan dalam rumah tangga (KDRT) pada 2004, jumlah kekerasan terhadap perempuan melonjak hingga empat kali lipat. Dari 7787 kasus pada 2003, menjadi 25.522 kasus pada 2007 yang ditangani 215 lembaga mita Komnas perempuan.”

Lebih jauh, wakil ketua Komnas perempuan Ninik Rahayu menyatakan "jumlah kuantitatif meningkatnya kasus kekerasan dalam rumah tangga (KDRT) ini menjadi fenomena 'gunung es'. Sebab, angka yang sebenarnya terjadi tidak pernah terungkap. Seiring meningkatnya jumlah kekerasn itu, bentuk kekerasannya juga meluas. Kalau dulu hanya dalam bentuk kekerasan fisik dan psikologi, sekarang banyak muncul kekerasan seksual.” Ungkap Ninik di gedung Komnas Perempuan Jakarta kemarin ${ }^{13}$.

Benar adanya kalau dikatakan bahwa kekerasan terhadap perempuan adalah laksana 'fenomena gunung es'. Bahkan kekerasan itu sampai sekarang masih berlanjut. Mungkin, kekerasan terhadap perempuan itu sendiri juga akan terus berlanjut. Lantas, faktor apa saja yang menyebabkan tumbuh suburnya kekerasan pada perempuan?

\section{Ketimpangan Budaya dan Penafsiran}

Manakala kita membaca berbagai teks atau literatur yang membahas gender, akan kita jumpai berbagai alasan ataupun faktor yang menyebabkan langgengnya kekerasan yang menimpa perempuan. Berbagai literatur yang banyak mengupas pentingnya kesetaraan

\footnotetext{
12 Sindo, 29/3/08

${ }^{13}$ Sindo, Sabtu, 8/3/08
} 
gender itu banyak ditulis oleh berbagai kalangan, terutama mereka yang selama aktif menjadi 'organizer' PSW ataupun PSG yang bertebaran diberbagai kampus di tanah air. Beberapa diantaranya juga ditulis oleh kalangan pengamat masalah perempuan dan juga para anggota LSM yang aktif memperjuangkan hak-hak perempuan yang hilang akibat adanya 'sistem budaya yang timpang'.

Sistem budaya yang timpang ini cenderung merugikan kaum perempuan dalam berbagai aspek kehidupan. Dengan sistim budaya ini, perempuan menjadi 'tersubordinate'. Ia tidak boleh lebih dari laki-laki dalam banyak hal. Perempuan harus selalu dibawah bayang laki-laki, baik pendidikan, karier, organisasi, dll. Mereka tidak boleh lebih dari lakilaki. Oleh karenanya, dalam berbagai hal mereka tidak bisa seiring sejalan dengan kaum Adam. Karenanya, mereka tidak punya kebebasan untuk berkarier, apalagi karena dengan tingkat pendidikan mereka yang rendah. Lebih jauh, mereka tidak punya suara dalam rumah tangga. Sebab, suami sebagai “The only decision maker”. Mereka juga tidak bisa aktif berkecimpung dalam berbagai kegiatan organisasi social kemasyarakatan. Dengan kata lain, Sistem budaya yang timpang itu telah menyebabkan perempuan mengalami diskriminasi dalam berbagai aspek kehidupan. Pertanyaannya, sistim budaya apa yang telah 'mengkebiri' perempuan untuk bisa setara dengam para lelaki?

Banyak kaum feminis yang berpendapat banyak diskrimisasi gender disebabkan oleh adanya hubungan keluarga (suami - istri) yang didasarkan pada sistem patriarkhi. Sistem ini telah membuat membuat perempuan 'terpasung'. Mereka tidak dapat melakukan berbagai hal sebagaimana yang dilakukan oleh para pria. Mereka hanya menjadi penonton. Mereka harus selalu patuh. Utamanya untuk melayani suami!

Banyak yang bilang, kalau tugas utama mereka hanyalah di "dapur, sumur, dan kasur." Dan kalau ada kekurangan dalam pelayanan yang mereka berikan pada para suami tersebut, mereka hanya bisa pasrah manakala suami melakukan tindak kekerasan. Mereka seolah tidak punya kekuatan untuk melawan keterjajahan yang selama ini mereka alami. Apalagi ditopang dengan tingkat pendidikan yang rendah. Hal ini semakin menjadikan mereka sebagai mahkluk lemah yang rentan terhadap berbagai tindak kekerasan.

Merekapun tidak mampu melindungi diri mereka sendiri. Bahkan, mereka menjadi sosok yang sangat tergantung pada mahkluk lain, terutama kaum Adam. Dalam hal ini, mereka memang hidup dalam lingkup budaya patriarkhi. Budaya patriarkhi ini pulalah yang pada akhirnya menimbulkan adanya ketimpangan gender dalam banyak hal.

Hal ini senada dengan pendapat Dzuhayatin ${ }^{14}$ yang menyatakan bahwa budaya patriarkhi terjadi karena adanya dominasi kelompok tertentu terhadap kelompok lain. Kelompok I tidak saja berbuat secara fisik terhadap kelompok II, tapi juga menentukan

\footnotetext{
${ }^{14}$ Dzuhayatin, dkk. S.R. et.al. 2002. Rekonstruksi Metodologis Wacana Kesetaraan Gender Dalam Islam. Yogyakarta: Pustaka Pelajar. (2002:11)
} 
ideologi budaya yang melanggengkan kekuasaannya. Mereka mengkontrusi nilai, norma dan moralitas yang mempertinggi kedudukan mereka dalam komunitas yang mereka kuasai.

Lebih jauh Sugihastuti ${ }^{15}$ menyatakan ketimpangan gender adalah perbedaan kedudukan (hak dan kewajiban) antara laki-laki dan perempuan di masyarakat yang menempatkan perempuan dalam status lebih rendah daripada laki-laki. "Hak istimewa" yang dimiliki oleh laki-laki seolah-olah menjadikan perempuan sebagai barang milik lakilaki yang berhak diperlakukan semena-mena termasuk dengan cara kekerasan.

Sementara itu, Max Weber, (dikutip R.A. Lydie, 1989) mengklasifikasi masyarakat semacam ini sebagai masyarakat patriarkhi dengan dominasi kekuatan laki-laki dewasa (patriach)...Konstruk budaya patriarkhi yang mapan secara universal dan berlangsung selama berabad-abad tidak dipandang lagi sebagai ketimpangan, bahkan di'klaim' sebagai fakta alamiah. Telah berabad-abad pula para perempuan dan para budak harus menerima nasib bahwa mereka lahir untuk melayani kepentingan laki-laki dewasa yang berkuasa ${ }^{16}$.

Selain disebabkan oleh adanya sistem patriarkhi yang sudah membudaya dan berlaku dimasyarakat kita sekian lamanya, kekerasan terhadap perempuan juga dapat diakibatkan oleh adanya penafsiran yang kurang 'pas' terhadap ayat al Qur'an. Penafsiran yang kurang 'pas' itu rupanya semakin mengukuhkan keberadaan system patriarkhi yang telah mengakar kuat disebagian besar rakyat Indonesia. Dzuhayatin ${ }^{17}$ menyatakan bahwa keterpurukan perempuan dalam Islam juga disebabkan oleh interpretasi yang bias patriarkhi terhadap poligami. Sebab konsep dasar poligami yang tercantum dalam surat an Nisa:3 dimaksudkan sebagai jaminan sosial bagi anak yatim dan para janda: "Jika kamu takut tidak dapat berbuat adil dalam menjamin hak-hak anak yatim (apabila kamu menikahi), maka kawinilah wanita-wanita (yang lain) yang kamu senangi: dua, tiga, dan empat. Dan apabila kamu tidak dapat berbuat adil, maka kawinilah hanya satu.” Ayat ini merupakan peringatan bagi laki-laki Arab yang cenderung mengawini anak yatim hanya untuk menguasai hartanya. Dalam konsep Islam, perkawinan semacam ini merupakan 'perbuatan aniaya' yang lebih berat daripada mengawini perempuan dua, tiga dan empat. Dan asas keadilan yang dijunjung tinggi dalam Islam dalam perkawinan adalah monogamy.

Jadi jelas bahwa kekerasan terhadap perempuan disebabkan oleh adanya budaya patriarkhi yang mengakar dan juga bias tafsir yang cenderung tidak memihak perempuan terhadap ayat al Qur'an. Mufidah ${ }^{18}$ juga menyatakan bahwa Penafsiran yang bias gender dan budaya patriarkhi terhadap perempuan menyebabkan lemahnya responsibilitas agama dalam menanggapi isu munculnya kasus kekerasan terhadap perempuan dan anak-anak yang akhir-akhir ini semakin santer muncul dipermukaan. Oleh karena itu, harus

\footnotetext{
${ }^{15}$ Sugihastuti Gender dan Inferioritas Perempuan (2007)

${ }^{16}$ Dzuhayatin, Rekonstruksi Metodologis , 10, 2002

${ }^{17}$ Ibid 18.,

${ }^{18}$ Mufidah, dkk. Haruskah Perempuan dan Anak di Korbankan (2006:29)
} 
dikembangkan semangat Islam sebagai suatu kekuatan untuk mencegah kekerasan terhadap perempuan dan anak yang lebih sensitive dan responsive terhadap kepentingan mereka.

Melihat fenomena kekerasan terhadap perempuan yang salah satunya disebabkan oleh adanya penafisaran yang kurang 'pas' terhadap ayat al Qur'an di atas, lantas, apakah Islam mendukung kekerasan terhadap perempuan? Jawabnya , tentu saja tidak. Larangan berbuat kekerasan dalam Islam tidak hanya berlaku bagi perempuan saja tapi juga bagi semua insan dibumi ini. Hal ini senada dengan bunyi sebuah hadist yang diriwayatkan oleh Dar al Quthi dan Ibnu Said al Khudri; "Janganlah membuat aniaya dan jangan pula dianaiya". Dalam hadist yang lain yang diriwayatkan oleh al Turmudzi:"Ingatlah aku berpesan agar kalian berbuat baik terhadapperempuan karena mereka sering menjadi sasaran pelecehan diantara kalian, padahal sedikitpun kalian tidak berhak memperlakukan mereka, kecuali untuk kebaikan itu." 19

Lebih jauh Mufidah ${ }^{20}$ menyatakan agama Islam sebagai agama yang rahmatan lil'alamin memiliki nilai-nilai universal untuk menjawab kebutukan terhadap pembebasan bagi perempuan dan anak-anak yang mengalami penindasan. Nilai-nilai itu diantaranya keadilan (al 'adalah), demokrasi (al dimokratiyah), kesetaraan (muwathanah), penegakan HAM (iqamat al huquq al insaniyyah), dan kemaslahatan (mashalih al ummah).

Merujuk nilai-nilai Islam di atas, dapat dikatakan bahwa kekerasan merupakan suatu tindak penindasan, kesombongan, kerusakan, dan menghilangkan hak-hak dasar manusia adalah bertentangan dengan nilai-nilai Islam. Islam juga menentang adanya kekerasan terhadap perempuan. Bahkan bukan hanya pada perempuan, tapi pada semua mahkluk dimuka bumi. Menilik nilai-nilai islam di atas dapat disimpulkan bahwa Islam itu adalah mulia, damai, bijak, adil, dan juga manusiawi. Namun melihat fenomena kekerasan terhadap perempuan yang tiada hentinya itu, apa yang bisa kita lakukan untuk mencegah atau kalau tidak meminimalisir kasus kekerasan terhadap perempuan yang banyak terjadi di tanah air tercinta ini?

\section{"Super Women" Sebagai Solusi}

"Super Women" mungkin merupakan istilah yang asing di telinga kita. Istilah ini bahkan tidak popular. Ada istilah lain yang lebih popular, yaitu "Super Man". "Super Man" begitu terkenal di negeri kita. Ia bahkan digandrungi oleh banyak kalangan. Anakanak, remaja/ pemuda sampai ke orang tua tahu siapa itu "Super Man".

Begitu terkenalnya tokoh ini, hingga kostum yang dipakainyapun diperjual belikan. Ketenarannya dalam membela kebenaran dengan memberantas segala bentuk kejahatan yang ada di Negara Super Power, Amerika Serikat, telah menempatkannya sebaga seorang Hero. Dan melalui filmnya yang diputar banyak Negara, semakin melambungkan namanya.

\footnotetext{
${ }^{19}$ Ibid 30

${ }^{20}$ Ibid 32.,
} 
Akhirnya label Hero, dengan segala kebajikan yang telah ia lakukan, menjadikannya sebagai pahlawan dunia. Namanyapun semakin berkibar dan mengglobal.

Namun sayang! Tokoh "Super Man" ini hanyalah sebatas tokoh fiksi. Ia hanyalah tokoh yang hadir sebagai akibat dari suatu creative thinking process seorang penulis cerita fiksi yang kemudian dituangkan dalam sebentuk creative writing. Dengan demikian, ia hanyalah seorang tokoh khayal. Ia tidak dapat dijumpai dikehidupan nyata. Kehadirannya hanya dapat ditonton difilm-film yang diputar oleh berbagai gedung bioskop ataupun televisi ataupun dibuku-buku 'komik'.

Hal ini tentu saja lain dengan "Super Women". Sebab, kalau "Super Man" hanyalah seorang tokoh khayal yang dapat kita tonton di dalam film namun, tidak demikian dengan "Super Women". "Super Women" adalah seorang tokoh nyata. Ia benar-benar ada. Dan walaupun ia tidak seterkenal "Super Man", keberadaannya dimuka bumi ini diakui ada. Dalam beberapa hal, keberadaan mereka diakui oleh banyak kalangan terutama melalui karya-karya yang telah mereka lakukan. Lantas, siapa itu "Super Woman"? Apa pula yang telah mereka lakukan berkaitan dengan kekerasan terhadap perempuan?

Istilah "Super Women” turut dipopulerkan oleh Sylvia Rabiner. Ia adalah seorang penulis kelahiran New York Amerika Serikat. Latar belakang pendidikannya didapat dari Hunter College dan juga New York University. Tulisan-tulisannya banyak dimuat berbagai media seperti Mademoiselle, Working Mother, dan The New Republic. "Super Women" adalah salah satu tulisannya yang mencerminkan gambaran tentang sosok wanita sukses yang ideal. Menurut Rabiner perempuan bisa disebut sebagai seorang "Super Women" apabila mereka dapat meraih 2 sukses dalam hidupnya. Yaitu 1) Sukses dalam karier; dan 2) Sukses dalam keluarga. ${ }^{21}$

Dari konsep Rabiner tentang "Super Women" di atas, dapat dijabarkan sebagai berikut. Sukses "Super Women" dalam karier dapat diukur dengan dimilikinya karier tetap yang menempatkannya sebagai seseorang yang keberadaannya sangat dibutuhkan di masyarakat. Dengan memiliki karier tetap, mereka akan memiliki penghasilan sendiri. Hal ini membuat mereka mandiri dan tidak terlalu tergantung pada suami mereka. Lebih jauh, dengan karier yang mereka miliki tersebut, langkah mereka dalam menjalani hidup menjadi semakin ringan. Tidak tambah 'ruwet'. Karena mereka memiliki sebuah "Internal Commitment" untuk selalu memperdalam ilmu dan juga menambah pengalaman hidup mereka. Dengan demikian, mereka akan selalu fokus dengan karier dan cenderung dapat mengatasi berbagai persoalan yang ada. Adapun contoh karier yang bisa disandangnya antara lain tenaga pengajar (guru/ dosen), penulis (novel, teks book, dll), pengacara, hakim, jaksa, sekretaris, auditor, akuntan, ekonom, politisi, budayawan, dan berbagai jabatan public lainnya.

\footnotetext{
${ }^{21}$ McCuen, Reading for Writing (1983:54)
} 
Selain sukses dalam karier, "Super Women" juga dituntut untuk sukses dalam rumah tangga. Untuk itu, "Super Women" biasanya sudah memprogram berbagai kegiatan yang mereka miliki. Hal ini mereka lakukan dengan baik agar waktu untuk karier tidak berbenturan dengan waktu untuk suami dan anak. " A Good Time Management by A Good Manager", itulah motto mereka. Sehingga sesibuk apapun mereka mengerjakan semua tugas yang berkaitan dengan karier, mereka tetap punya waktu untuk suami dan juga anakanak. Karena itu, mereka biasanya memanfaatkan waktu untuk keluarga se-efisien mungkin. Contohnya adalah dengan bertamasya bersama keluarga (suami dan anak) ke berbagai tempat wisata, makan bersama, ataupun melakukan berbagai kegiatan lainnya yang bersifat sosial ataupun keagamaan sekeluarga bersama-sama. Berbagai kegiatan keluar bersama ini benar-benar mereka manfaatkan sebagai sarana efektif untuk menjalin kebersamaan, pengertian dan saling perhatian guna menggapai kebahagiaan keluarga.

Dengan menjadi “Super Women”, perempuan akan dapat melindungi diri mereka sendiri. Sehingga mereka dapat mencegah berbagai kekerasan yang selama ini sering menimpa mereka. Bahkan, mereka dapat mengabdikan hidup mereka untuk keluarga. Dengan demikian pada saat mereka mencapai kesuksesan karier, kehidupan rumah tangga merekapun juga semakin harmonis. Selalu ada saja waktu buat suami dan anak-anak. Oleh karena itu, walaupun disibukkan dengan 'seabrek' tugas kantor sebagai konsekwensi dari dari karier yang mereka jalani, berbagai acara keluarga selalu saja dapat mereka lakukan.

Namun konsep "Super Women” Rabiner di atas belumlah lengkap. Ada bidang krusial lainnya yang belum mereka lakukan guna memaksimalkan peran mereka. Bidang itu adalah organisasi sosial kemasyarakatan. Dengan demikian, belumlah cukup bagi perempuan dengan hanya mencapai sukses karier dan keluarga. Mereka juga juga dituntut untuk sukses organisasi sosial kemasyarakatan.

Selain itu, peran perempuanpun akan menjadi semakin lengkap jikalau mereka juga dapat mencapai sukses religi. Kesusksesan religi ini sangat penting peranannya dalam karier hidup perempuan. Kesuksesan religi akan memandu perempuan menjalankan berbagai perannya di keluarga, kantor, dan masyarakat dengan baik.

Tentu saja, konsep "Super Women" Rabineer di atas akan semakin lengkap apabila perempuan juga dapat meraih sukses organisasi sosial kemasyarakatan dan juga sukses religi selain sukses karier dan sukses keluarga. Dalam hal ini, dengan bekal keimanan yang kuat, walau disibukkan dengan berbagai tugas kantor dan keluarga, mereka tetap saja punya waktu untuk masyarakat. Hal ini mereka wujudkan dengan aktif menjadi salah satu anggota organisasi sosial kemasyarakatan yang ada. Dengan demikian kehadiran mereka diorganisasi tersebut akan benar-benar bermanfaat bagi organisasi tersebut pada khususnya dan masyarakat pada umumnya. Kemanfaatan mereka untuk masyarakat dilandasi oleh keyakinan mereka akan peran manusia sebagai "social creature" dan adanya kesadaran 
tentang "inclusivism" dan bukan "exclusivism" yaitu asas manfaat individu bagi semua orang dan bukan hanya bagi sekelompok orang saja.

Itulah sekilas gambaran tentang "Super Women”. Pertanyaannya, Perempuan mana yang tidak ingin seperti "Super Women"? Perempuan mana yang tidak ingin bahagia dalam hidupnya dengan mencapai berbagai sukses di atas?; Kalau hal itu dapat mereka gapai, tentunya hidup mereka akan sempurna. Bagaimana tidak? Sosok 'Super Women” tampil sempurna dengan segala kesuksesan mereka. Hal inilah yang akan membuat perempun mandiri, bermartabat dan tentunya mulia.

Namun, untuk mencapai derajat "Super Women" bukanlah hal mudah. Ada syarat utama yang harus dipenuhi perempuan. Syarat ini begitu penting, Bahkan, syarat ini sama pentingnya dengan air yang mereka minum. Syarat inipun sama pentingnya dengan udara yang mereka hirup tiap detiknya. Dan perempuan, punya potensi untuk menjadi sosok "Super Women". Namun, mereka harus memenuhi dulu syarat utamanya. Sehingga tanpa adanya syarat ini, menjadi "Super Women” hanyalah sebatas impian belaka. Lantas, syarat apakah yang akan mengantarkan perempuan dari ketidak berdayaan kepada suatu keperkasaan, "Super Women"?

Pendidikan! Ya, syarat utama itu adalah pendidikan. Namun bukan pendidikan yang apa adanya. Pendidikan yang harus dipenuhi perempuan untuk mengantarkan mereka menjadi "Super Women" adalah pendidikan tinggi. Jadi, perempuan harus mendapatkan pendidikan yang lebih dari cukup. Jangan hanya pendidikan rendah. Artinya, mereka tidak boleh puas dengan pendidikan yang selama ini telah mereka dapat. Sebaliknya, mereka harus terus berusaha meningkatkan ilmu dan juga kemampuan mereka.

Begitu pentingnya pendidikan itu, sehingga ia bisa merubah posisi perempuan dari hidup yang serba terjajah dan terpuruk kepada suatu kehidupan yang lebih bermartabat dan mulia. Hal ini senada dengan pendapat Roqib yang menyatakan bahwa pendidikan dapat menciptakan ruang agar bersifat kritis terhadap sistim dan struktur yang diskriminatif terhadap kaum tertindas dan kaum tersingkirkan, seperti kaum miskin, kaum buruh, para penyandang cacat, atau mereka yang memiliki kemampuan berbeda, kaum perempuan, anak-anak serta bagaimana melakukan proses dekonstruksi dan berbagai aksi praktis ataupun strategis menuju system social yang sensitive dan non diskriminatif. ${ }^{22}$

Sementara itu, Djojonegoro ${ }^{23}$ menyatakan apabila kaum perempuan memiliki ilmu dan kemampuan yang tinggi, ia dapat bersikap lebih arif, dewasa dan terhormat sehingga tidak lepas dari mulut singa kemulut buaya....Untuk perempuan dengan ilmu dan ketrampilan yang dimiliki, diharapkan dapat berkiprah lebih proporsional sesuai dengan kewajiban, hak, kapasitas perempuan, dan ketrampilannya. Manifestasi peran semakin mudah apabila perempuan (muslimah) dapat menguasai dan memanfaatkan ilmu pengetahuan dan teknologi yang berkembang.

\footnotetext{
${ }^{22}$ Roqib, Pendidikan Perempuan 2003:xxv

${ }^{23}$ Ibid 4
} 
Dengan pendidikan tinggi tersebut, perempuan akan setara dengan laki-laki. Mereka tidak lagi tersubordinate. Mereka tidak akan menjadi warga kelas dua. Mereka dapat berperan dalam berbagai aspek kehidupan seiring sejalan dengan kaum pria. Athiyah juga menegaskan bahwa dengan ilmu dan pendidikan perbedaan kelas antara manusia dapat diperkecil dan sebaliknya persamaan dapat diwujudkan, kesempatan yang sama dapat diciptakan... ${ }^{24}$.

Lebih jauh Athiah menjelaskan bahwa hanya dengan pendidikan perempuan dapat menjadi sosok yang berfikir kreatif. Adapun tanda-tanda orang berfikir kreatif antara lain (1) kemampuan kognitif, termasuk kecerdasan di atas rata-rata dan kemampuan melahirkan gagasan-gagasan baru; (2) sikap terbuka, yaitu siap menerima stimuli internal dan eksternal; ia juga memiliki sikap yang beragam dari luar; (3) sikap yang bebas, otonom dan percaya pada diri sendiri, yaitu memiliki gaya "hidup" tersendiri terbebas dari polusi lingkungannya ${ }^{25}$.

\section{Kesimpulan}

Dari pembahasan di atas, dapat disimpulkan bahwa hanya dengan pendidikan, perempuan akan dapat berubah menjadi "Super Women". Sehingga mereka dapat tampil sebagai sosok yang cerdas, mandiri, kreatif, inovatif, berjiwa sosial dan agamis yang akan mengantarkan perempuan pada suatu kesuksesan dalam karier, keluarga dan organisasi yang dipandu dalam koridor kesuksesan religi. Pada gilirannya, mereka dapat mengentaskan diri mereka sendiri dari keterpurukan dan keterjajahan yang termanifestasi dalam berbagai bentuk kekerasan yang membelenggu begitu lama akibat adanya sistim budaya yang 'timpang' dan tafsir ayat yang tidak 'pas' yang tiada pernah memihak perempuan. Dengan demikian, dengan menjelma menjadi sosok "Super Women", nasib perempuan tidak akan selalu terjajah seperti contoh syair di atas: ..."Wanita dijajah pria sejak dulu. Dijadikan perhiasan sangkar madu...Sebaliknya, perempuan dapat menjelma menjadi sosok yang mandiri, bermartabat dan mulia yang berguna bagi diri mereka sendiri, keluarga, masyarakat, dan negara. Jika demikian, wahai perempuan, siapkah anda menjadi 'Super Women"? 


\section{Referensi}

Dzuhayatin, S.R. et.al. 2002. Rekonstruksi Metodologis Wacana Kesetaraan Gender Dalam Islam. Yogyakarta: Pustaka Pelajar.

Roqib, M. 2003. Pendidikan Perempuan. Yogyakarta: Gama Media

McCuen, JR. 1983. Reading for Writing. London: Harcourt Brace Jovanovic, Publishers.

Mufidah, Et.al. 2006. Haruskah Perempuan dan Anak di Korbankan. Yogyakarta: Pilar Media.

Sugihastuti \& Saptiawan, I. 2007. Gender dan Inferioritas Perempuan. Yogyakarta: Pustaka Pelajar.

Thalib, M. 1999. Solusi Islam Terhadap Dilema Wanita Karier. Yogyakarta: Wihdah Press. Jawa Pos, Edisi Senin, 10/3/08

Surya, Edisi Minggu, 2/3/08

Surya, Edisi Selasa, 4/3/08

Sindo, Edisi Sabtu, 8/3/08

Sindo, Edisi Minggu, 9/3/08

Sindo, Edisi Selasa, 11/3/08

Sindo, Edisi Rabu, 12/3/08

Trans 7, Kamis, 13/3/08 
